\title{
USE OF MICROBES FROM SEABIRD FAECES TO EVALUATE HEAVY METAL CONTAMINATION IN ANTARCTIC REGION
}

\author{
S. SAIKIA ${ }^{1}-$ D. SAIKIA ${ }^{2}-$ PW RAMTEKE $^{1 *}$ \\ ${ }^{1}$ Industrial Toxicology Research Centre (CSIR), Lucknow \\ ${ }^{2}$ Central Institute of Medicinal and Aromatic Plants (CSIR), Lucknow, India \\ Allahabad-211007, Uttar Pradesh, India \\ *Corresponding author \\ e-mail:pwramteke@yahoo.com
}

\begin{abstract}
(Received $31^{\text {st }}$ January 2007 ; accepted $24^{\text {th }}$ February 2008)
Abstract. This study evaluates the levels of heavy metal pollution in Antarctic marine ecosystem by monitoring gut microbial flora of seabird skua (Catharacta spp). Aerobic and anaerobic bacteria isolated from fresh faecal sample of skua were tested for their heavy metal tolerance and antibiotic resistance pattern. More than $50 \%$ isolates were able to tolerate $200 \mathrm{~g} / \mathrm{ml}$ concentration of lead $(\mathrm{Pb})$, chromium $(\mathrm{Cr})$, zinc $(\mathrm{Zn})$ and nickel $(\mathrm{Ni})$ and $>80 \%$ isolates showed resistance towards Bacitracin. More than $50 \%$ isolates were resistance to multiple antibiotics (MAR) and the the traits were found to be plasmid-borne in nature. The elevated rate of tolerance to the heavy metals reflects an adaptive response to the toxic metals present in marine environment.
\end{abstract}

Keywords: Antarctica, skua, gut microflora, heavy metals

\section{Introduction}

The largest and diverse ecosystem on the globe, Antarctica is considered as a major biotic province. Antarctica ecosystems are comprised of marine, freshwater, ice and terrestrial habitats. Besides microbial population, a number of bird species also inhabit Antarctica, which includes polar skuas (Catharacta spp). Pollutant level determination in polar skuas (Catharacta spp) are interesting, as this species has one of the longest migration of any birds, taking it through polluted wastes of the Northern Hemisphere (Devillers, 1977) as far north as the Grand Banks of Newfoundland (Veit, 1978) and Greenland (Fullager, 1976). Seabirds, which are top predators, are predominantly studied for monitoring changes in lower trophic levels of the marine food chain (Bourne, 1976; Furness and Monaghan; 1987). Because seabirds are conspicuous creatures, they are a suitable choice to play a role as sentinel organisms. Seabirds can range over huge areas of the ocean when feeding or migrating, and many accumulate high concentrations of anthropogenic pollutants while foraging during these flights (Risebrough \& Carmignani, 1972; Bull et al, 1977; Furness and Hutton, 1979, 1980; Gardner et al, 1985). Some pollutants are characteristically lipid-soluble but have low water solubility such as organo-chlorines and organo-metallic compounds. Thus, seabirds are appropriate as monitors of food chain exposure to lipid soluble pollutants (Furness, 1993).

The seabirds, skua (Catharacta spp.) are scavengers in nature but now they have made their foster home in Antarctica. These birds visit Antarctica during summer season and migrate towards Arctic Ocean during winters. Catharacta spp are top predators feeding on fishes and other seabirds. They make their nests around places of human habitation. Being migratory and top predators in marine ecosystem, skuas are ideal species through which to monitor trends in oceanic pollution (Furness, 1987). .Since microbial flora of any habitat indicates the environmental quality status and the exploitation or pollution levels of that particular area this study was attempted with a 
view to assess the pollution levels of Antarctica marine ecosystems by analysing the gut microbial flora of an Antarctic seabird skua (Catharacta spp).

\section{Materials and methods}

\section{Sampling}

Sampling was performed during the mid -summer period (during $18^{\text {th }}$ Indian Expedition to Antarctica, January, 1999). Stool sample from Antarctic skua was collected from the vicinity of Indian station "Maitri" of the Schirmacher Oasis (Queen Maud Land) which is situated in the geographical coordinates of $70^{\circ} 45^{\prime} 12^{\prime \prime} \mathrm{S}$ and $11^{\circ}$ 46' E.

Flying individual was tracked using 10x42 binoculars and fresh fecal matter of the skua delivered on a rock was collected aseptically in a sterile container and subjected for bacteriological analysis immediately

\section{Microbiological analysis}

Faecal sample was homogenized thoroughly with sterile phosphate buffer saline $(\mathrm{pH}$ 7.0) for the isolation of bacteria. Sample was appropriately diluted and plated by the standard spread plate method (APHA, 1992) on plate count agar and anaerobic agar (Hi-Media Ind. Pvt. Ltd.) plates. The inoculated plates were incubated aerobically and anaerobically respectively at room temperature $\left(24^{\circ} \mathrm{C}\right)$ for 24 hours. After appropriate incubation, clones representing different colony types were purified on Mac Conkey agar plates.

\section{Characterization of bacterial isolates}

Twenty-two colonies purified on the basis of morphological differences were subjected to different morphological and biochemical tests such as gram staining, oxidase, catalase, TSI, etc and were characterized according to Cowan and Steel (1974).

\section{Evaluation of heavy metal tolerance}

Tolerance of faecal bacteria to various heavy metals was determined by agar dilution method (Cervantes et al., 1986). In agar dilution method, plates were prepared freshly by supplementing agar medium with metal salts to give a final cationic concentration in $\mu \mathrm{g} / \mathrm{ml}$ of 50,100, 200, \& 400 for $\mathrm{Cd}^{2+}, \mathrm{Cu}^{2+}, \mathrm{Zn}^{2+} \mathrm{Ni}^{2+} \mathrm{Pb}^{2+} \mathrm{As}^{2+} \mathrm{Cr}^{2+}$ and $50 \& 100$ for $\mathrm{Hg}^{2+}$. The compounds used were $\mathrm{Cd}\left(\mathrm{NO}_{3}\right)_{2}, \mathrm{CuCl}_{3}, \mathrm{ZnCl}_{2}, \mathrm{Ni}\left(\mathrm{NO}_{3}\right)_{2},\left(\mathrm{CH}_{3} \mathrm{COO}\right)_{2} \mathrm{~Pb}$, $\mathrm{As}_{2} \mathrm{O}_{3}, \mathrm{~K}_{2} \mathrm{Cr}_{2} \mathrm{O}_{7}$, and $\mathrm{HgCl}_{2}$. Plate were inoculated and incubated aerobically \& anaerobically at room temperature $\left(24 \pm 2^{0} \mathrm{C}\right)$ for 24 hours. The minimum concentration of metals inhibiting complete growth was taken as minimal inhibitory concentration (MIC). 


\section{Determination of antibiotic resistance}

Susceptibility to different antibiotics was determined by Disc Diffusion method (Bauer et al., 1966). For determining antibiotic resistance, antibiotic impregnated discs were plated on Mueller-Hinton agar (Hi-Media Ind. Pvt. Ltd) plates that had been seeded with culture. The plates were incubated aerobically and anaerobically at room temperature $\left(\left(24 \pm 2^{0} \mathrm{C}\right)\right)$ for 3-4 days. The isolates were classified as resistant or susceptible following the standard disc sensitivity testing method (Difco, 1884). Discs containing the following antibiotics $\mu \mathrm{g} / \mathrm{discs}$ were tested; ampicillin (10), gentamycin (10); vancomycin (30), Tetracycline (30), Polymixin-B (50); chloramphenicol (30); Bacitracin (10); Streptomycin (25); Kanamycin (30), Neomycin (30), Carbenicillin (100); Nalidixic acid (30); cephaloridine (30), Co-trimaxazole (25) and Colistin (25).

\section{Plasmid curing: Spontaneous loss}

A total of eight isolates- six aerobic and two anaerobic, resistant to multiple antibiotics were selected for observing plasmid curing and spontaneous loss of resistance. Test organisms to be cured were inoculated in peptone water and were brought up to their logarithmic growth phase. Plasmid curing was observed by the application of curing agent, acridine orange. Tubes containing $10 \mathrm{ml}$ peptone water were supplemented with $20 \mu \mathrm{g} / \mathrm{ml}$ acridive orange and were inoculated with $0.1 \mathrm{ml}$ of over night grown broth culture and incubated at $37^{\circ} \mathrm{C}$ for 24 hours. Loop-full of inoculum was streaked on Mac Conkey agar plates to obtain single colony isolates having stress due to curing agent. After overnight incubation at $37^{\circ} \mathrm{C}$, resulting colonies were again tested for loss of heavy metals and antibiotic resistance for which the wild strain was found to be resistant. To determine spontaneous loss of plasmid, cultures were grown in peptone water tubes and transferred at regular intervals and the procedure described above was repeated.

\section{Results}

\section{Isolation and characterization results}

Isolation of bacteria yielded a total of twenty-two (22) pure colonies, among which six colonies were anaerobic in nature. The isolated organisms were found to be the members of family Enterobacteriaceae. Among the aerobic bacteria, 87.5\% of the isolates were found to be Escherichia coli (S-1, S-2, S-3, S-4, S-5, S-7, S-8, S-9, S-10, S-11, S-12, S-13, \& S-16) while 12.5\% isolates were characterised as Citrobacter (S-15, S-17). Thus altogether E. coli was the predominant genera (77.46\%) among the total number of isolates followed by Citrobacter and Providencia, both representing 9\% of the total population while Klebsiella $(4.54 \%)$ were the least reported species (Fig. 1). The anaerobic bacterial population represented $50 \%$ of the isolates as E. coli (SA-2, SA3, \& SA-6) followed by Providencia (33.33\%, SA-4, SA-5) and Klebsiella (SA-1) as $16.67 \%$ of the total anaerobes (Fig. 1). 


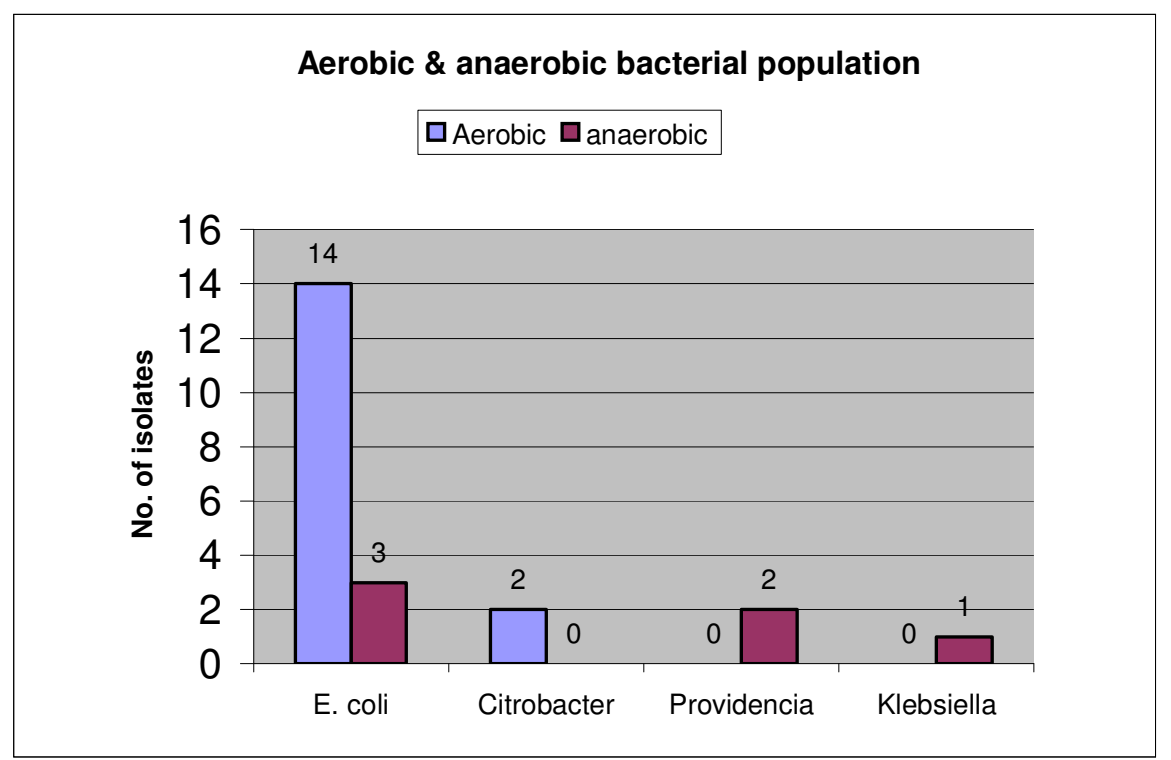

Figure 1. Types of bacterial strains from skua faeces

\section{Heavy metal tolerance}

The isolated organisms showed various levels of tolerance towards different heavy metals (Fig. 2). All the isolates, aerobic as well as anaerobic, were able to tolerate 50 $\mu \mathrm{g} / \mathrm{ml}$ concentration of all the heavy metals tested except for mercury $(\mathrm{Hg})$ for which only $68.1 \%$ of the isolates showed tolerance.

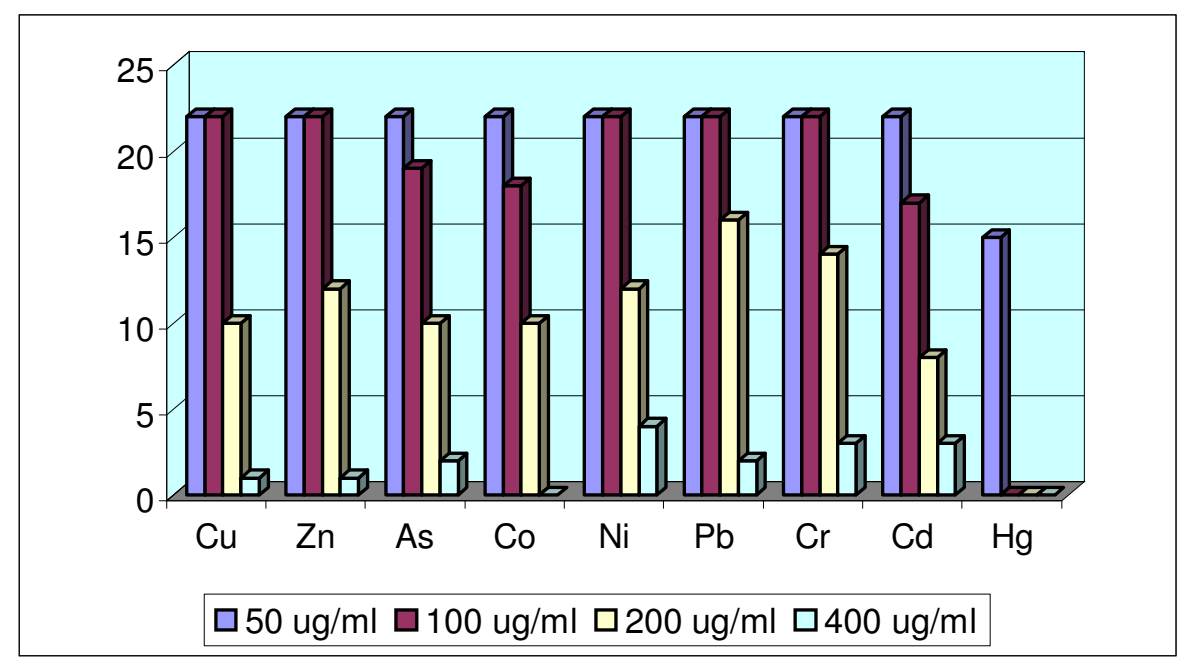

Figure 2. Heavy metal tolerance among bacterial isolates from skua faeces

Further, at $100 \mu \mathrm{g} / \mathrm{ml}$ concentration of $\mathrm{Hg}$, none isolate was found to be tolerant. However, a tolerance level at this concentration $(100 \mu \mathrm{g} / \mathrm{ml})$ was shown by maximum number of isolates (86.3\%) for Arsenic (As), followed by Cobalt (81.8\%) and Cadmium (77.2\%) isolates. At $200 \mu \mathrm{g} / \mathrm{ml}$ concentrations of heavy metals, maximum tolerance was observed for lead $(\mathrm{Pb})$ shown by $72.7 \%$ of the isolates followed by Chromium 
(63.6\%), Zinc and Nickel (54.5\%), Copper, Arsenic \& cobalt (46.4\%) and the least for Cadmium $(\mathrm{Cd})$ shown by $36.3 \%$ isolates. At the maximum concentration of heavy metal tested i.e.

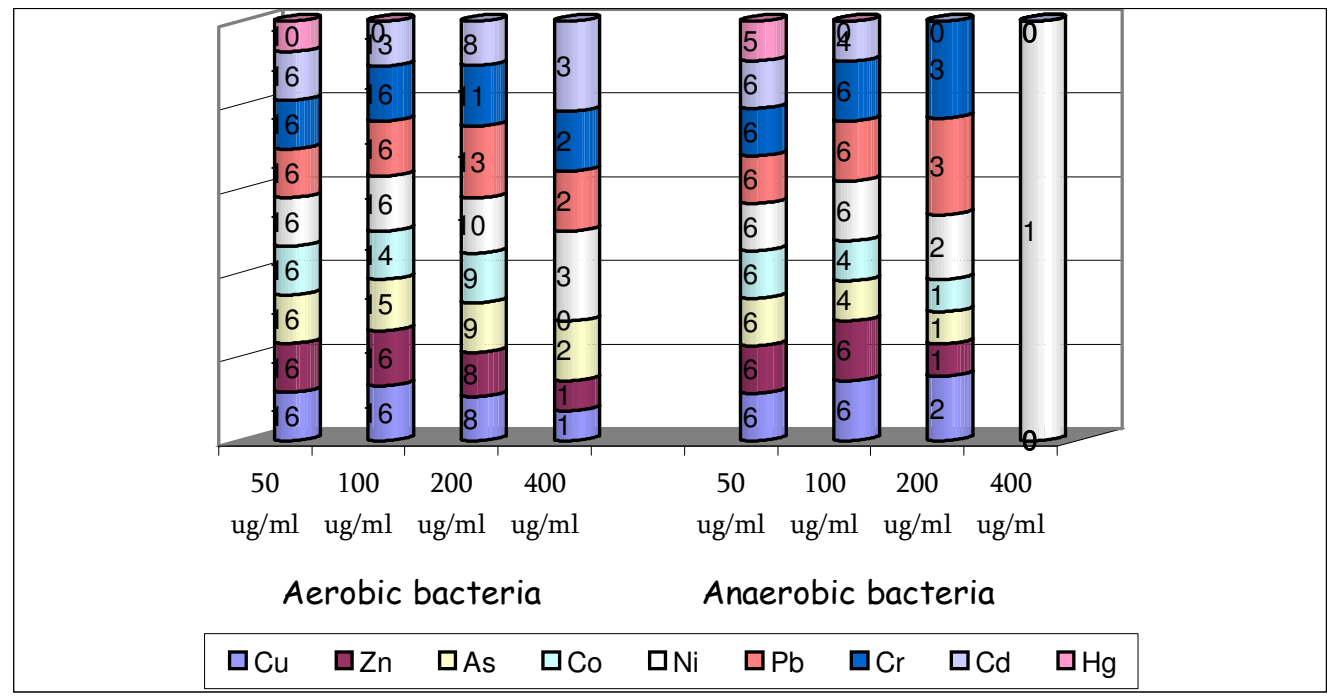

Figure 3. Comparative analysis of tolerance as shown by aerobic and anaerobic isolates for various heavy metals

$400 \mu \mathrm{g} / \mathrm{ml}$, highest tolerance was showed by $18.18 \%$ of the isolates for Nickel while $13.6 \%$ isolates showed tolerance for Chromium and Cadmium respectively. Tolerance for Arsenic and Lead was observed in $9.09 \%$ isolates and least tolerance was shown by $4.54 \%$ isolates for copper and zinc respectively. None isolate was found tolerant at this level of concentrations for cobalt.

Comparing the tolerance levels of these isolates on their aerobic and anaerobic nature, it was found that aerobic bacterial isolates were more tolerant towards heavy metals as compared to their anaerobic counterparts. A comparative analysis of tolerance as shown by aerobic and anaerobic isolates for various heavy metals is depicted in Fig. 3. Tolerance at higher concentration $(400 \mu \mathrm{g} / \mathrm{ml})$ was observed by $16.67 \%$ anaerobic isolates only for Nickel while no isolate was tolerant to rest of the heavy metals tested at this concentration.

Among aerobic bacteria none of the isolate showed tolerance for cobalt at $400 \mu \mathrm{g} / \mathrm{ml}$ concentration of heavy metals while maximum tolerance was revealed for Nickel and Cadmium by $18.75 \%$ isolates.

\section{Resistance to antibiotic}

The microbial isolates from Skua faeces showed a varied pattern of resistance towards different antibiotic (Fig. 4). Predominant resistance was observed for bacitracin showed by $81.8 \%$ of the isolates. $45 \%$ isolates were found to be resistant to both vancomycin and kanamycin while for streptomycin $36.3 \%$ of the isolates showed resistance. 


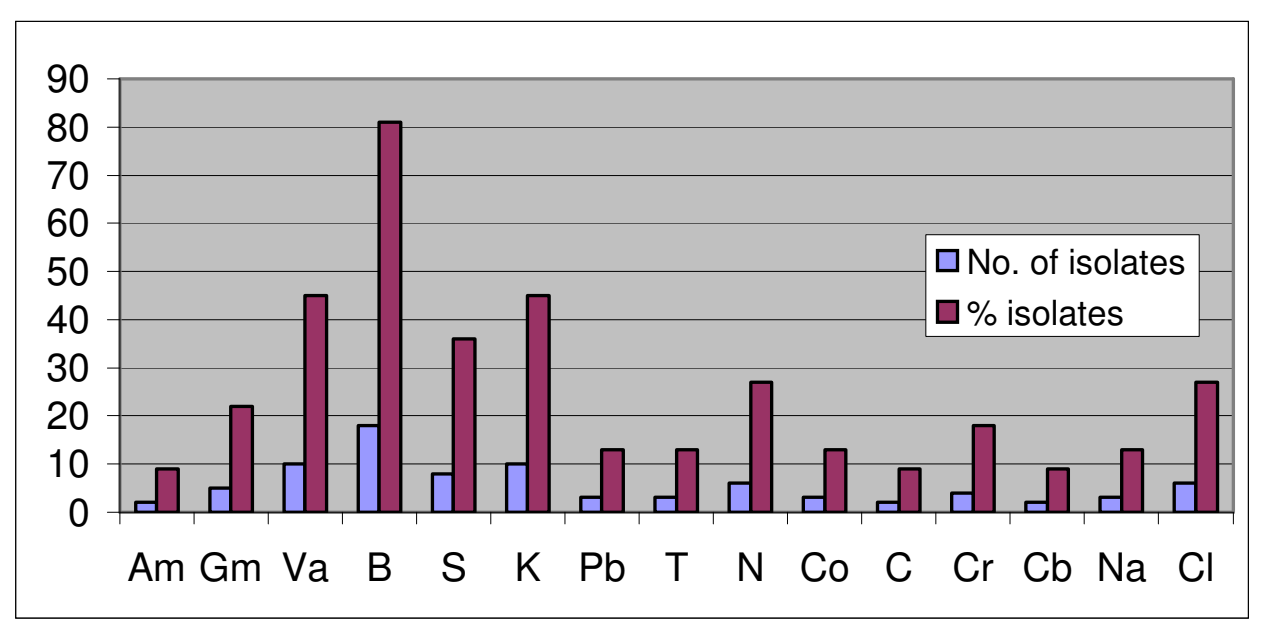

Am: ampicillin, Gm: gentamycin, Va: vancomycin, B: bacitracin, S: streptomycin, K: kanamycin, Pb: polymixin-B, T: tetracycline, $\mathrm{N}$ : neomycin, Co: Co-trimaxazole, C: Chloramphenicol, Cr: cephaloridine, Cb: Carbenicillin, Na: Nalidixic acid, Cl: Colistin

Figure 4. Antibiotic resistance among bacteria from skua faeces

Resistance for three antibiotics Gentamycin, Neomycin and Colistin was observed in $27.2 \%$ of the isolates. $18.1 \%$ isolates showed resistance for cephaloridine and $13.6 \%$ isolates were found to be resistant for polymixin-B, Tetracycline, Co-trimaxazole and Nalidixic acid. Least resistance was observed for Ampicillin, shown by $9.09 \%$ isolates.

As a comparative study for resistance among aerobic and anaerobic isolates aerobic strain were found to be more resistant to various antibiotics (Fig. 5).

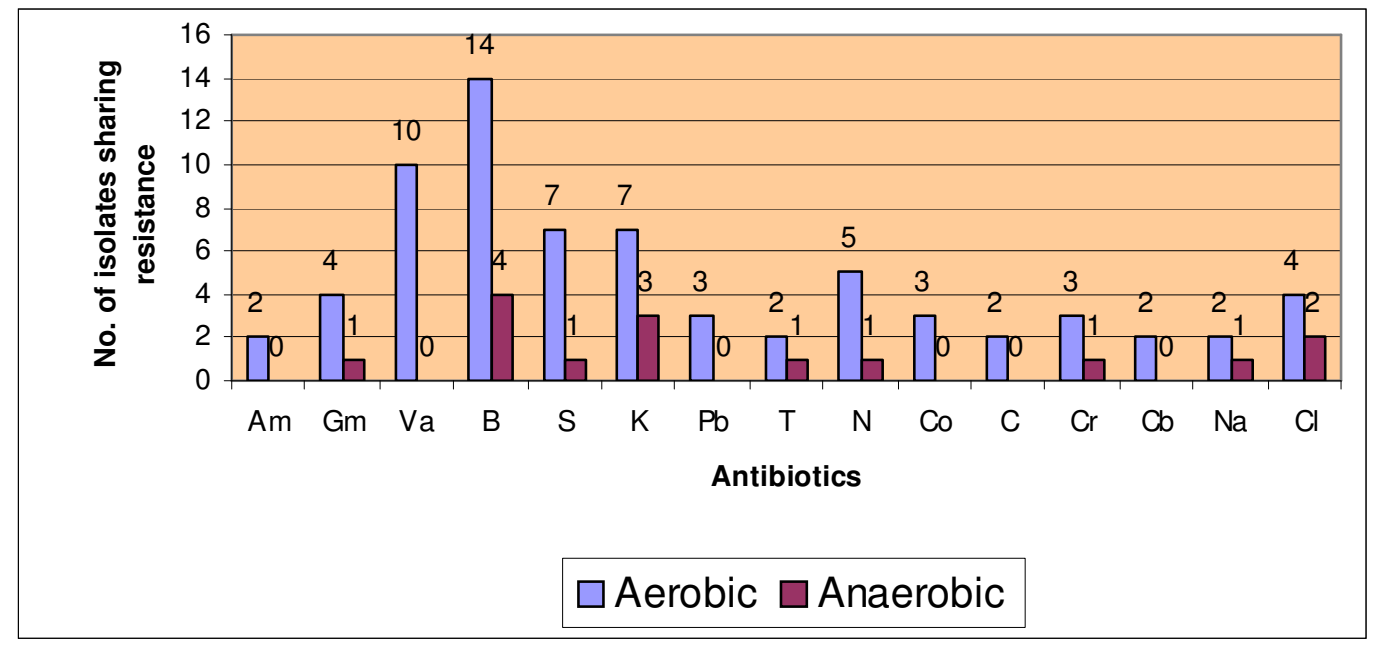

Figure 5. Comparison between aerobic versus anaerobic isolates sharing antibiotic resistance

None of the anaerobic isolate was found to be resistant against antibioticsAmpicillin, vancomycin, Polymixin-B, co-Trimaxazole, chloramphenicol and carbenicillin. Maximum resistance among anaerobic isolates was shown by $66.67 \%$ of the isolates for Gentamycin, streptomycin, tetracycline, Neomycin, Cephaloridine and Nalidixic acid.

Among aerobic isolates, predominant resistance was observed by $90 \%$ isolates for bacitracin, followed by vancomycin (65\%) and streptomycin and Kanamycin (both $45 \%$ 
isolates). Least resistance was shown by $12.5 \%$ isolates for a number of antibiotics (ampicillin, Tetracycline, chloramphenicol, carbenicillin and Nalidixic acid).

A graphical analysis between the number of isolates resistant to the number of antibiotics is shown in Fig. 6 which reveals that $59 \%$ of the isolates were resistant to multiple antibiotics (MAR) while one aerobic (S-12) isolate was fully susceptible to all the antibiotics tested; not showing resistance towards any antibiotic.

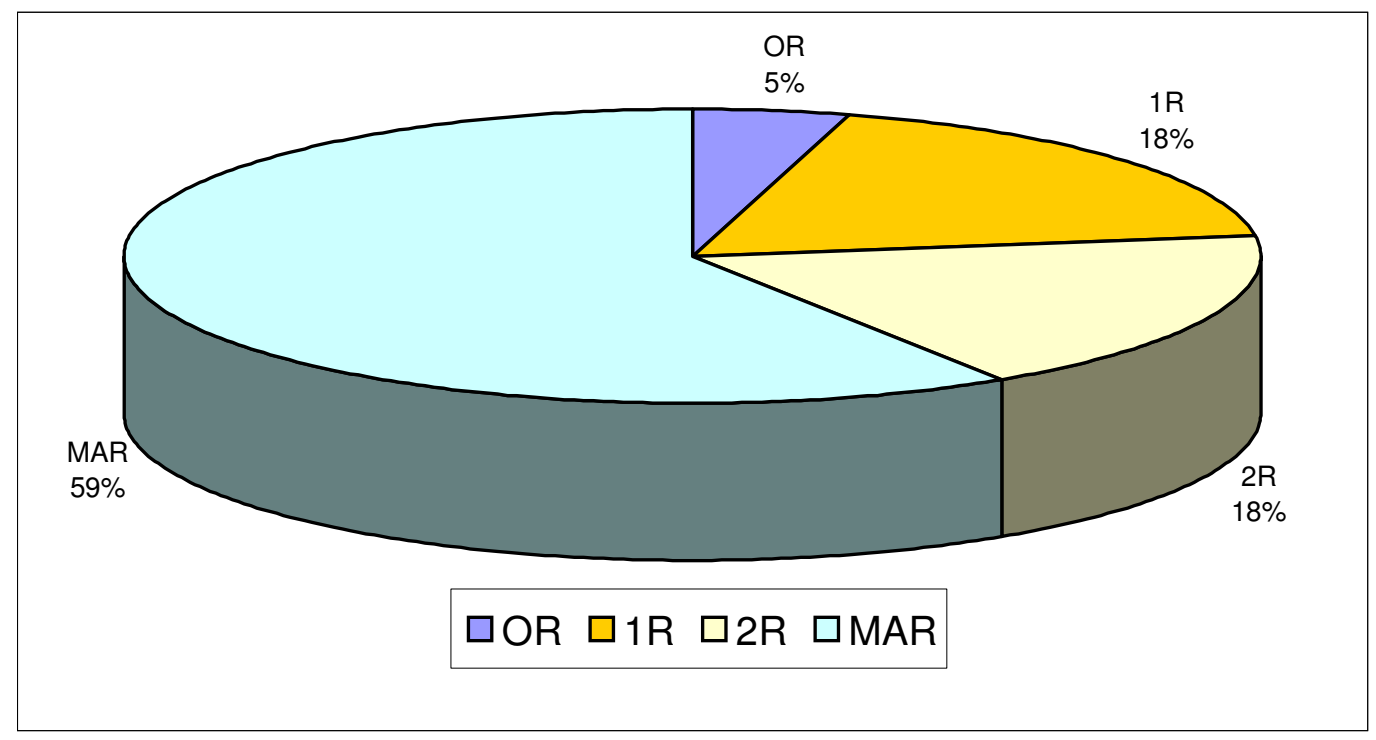

0R: susceptible to all antibiotics, 1R: resistant to one antibiotic, 2R: resistant to two antibiotics, MAR: resistant to multiple antibiotics

Figure 6. Antibiotic determinants among isolates from skua faeces

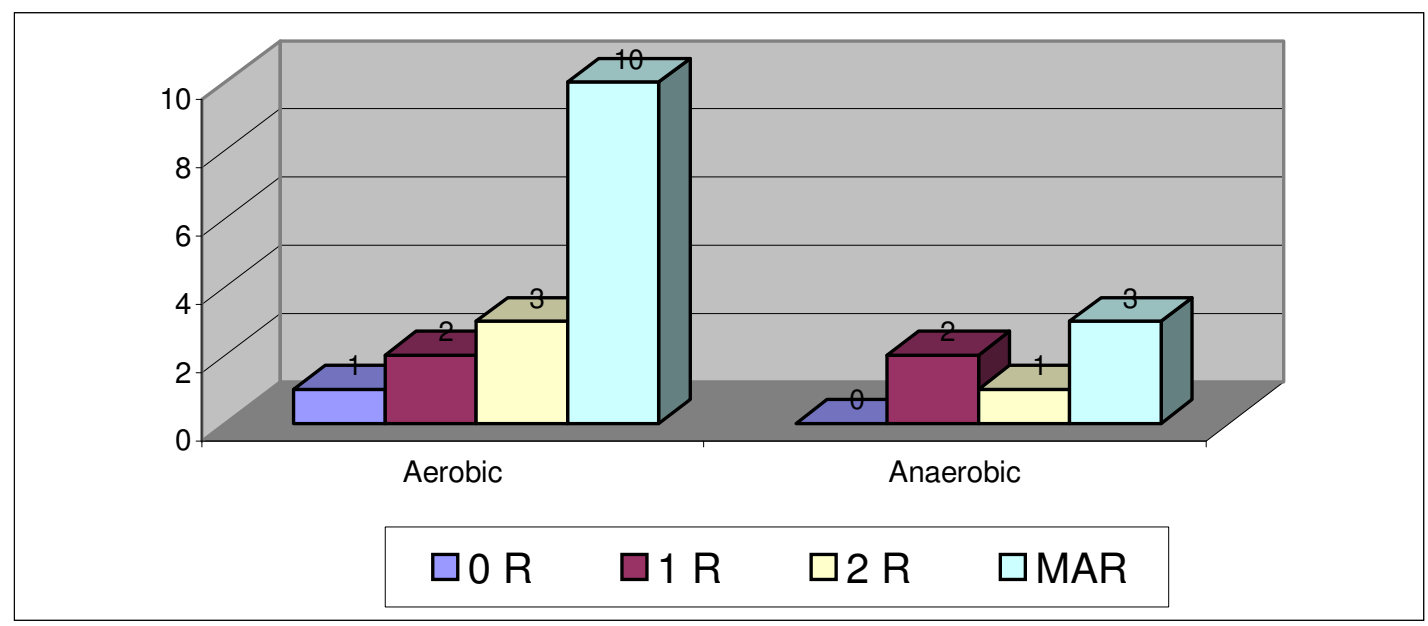

Figure 7. Comparative graphical analysis of aerobic and anaerobic isolates number resistant to the number of antibiotics. 


\section{Spontaneous loss of resistance and curing of plasmids}

Results of plasmid curing among isolates is depicted in Table 1. Most of the colonies showed no loss of resistance due to the presence of curing agents for Cadmium and Nickel. Cent percent curing was observed in one aerobic E. coli (S-10) for chromium while one anaerobic isolate of Providencia (SA-4) showed $100 \%$ loss of tolerance towards Cobalt. Two aerobic isolates of E. coli (S-2 and S-10) showed 90-100\% curing for copper.

Table 1. Loss of resistance in various isolates due to stress by curing agent

\begin{tabular}{|c|c|c|c|c|c|c|c|c|}
\hline \multirow{2}{*}{$\begin{array}{l}\text { Heavy } \\
\text { metals }\end{array}$} & \multicolumn{8}{|c|}{ Resistance \% } \\
\hline & $\begin{array}{c}\text { E. coli } \\
\text { (S-2) }\end{array}$ & $\begin{array}{c}\text { E. coli } \\
\text { (S-9) }\end{array}$ & $\begin{array}{l}\text { E. coli } \\
\text { (S-10) }\end{array}$ & $\begin{array}{l}\text { E. coli } \\
\text { (S-11) }\end{array}$ & $\begin{array}{l}\text { E. coli } \\
\text { (S-13) }\end{array}$ & $\begin{array}{c}\text { Citrobacter } \\
(\mathrm{S}-15)\end{array}$ & $\begin{array}{c}\text { Klebsiella } \\
\text { (SA-1) }\end{array}$ & $\begin{array}{c}\text { Providencia } \\
\text { (SA-4) }\end{array}$ \\
\hline Chromium & 30 & 0 & 100 & 78.3 & 85 & 0 & 0 & 70 \\
\hline Cadmium & 20 & 0 & 0 & 0 & 0 & 0 & 0 & 0 \\
\hline Copper & 90 & 76.6 & 96.6 & 0 & 0 & 0 & 0 & 0 \\
\hline Nickel & 61.6 & 0 & 43.3 & 0 & 0 & 0 & 0 & 0 \\
\hline Cobalt & 78.3 & 71.6 & 81.6 & 76.6 & 73.3 & 70 & 88.3 & 100 \\
\hline Antibiotics & & & & & & & & \\
\hline Streptomycin & 88.3 & 0 & 33.3 & 0 & 0 & 6.6 & 23.3 & 90 \\
\hline Kanamycin & 95 & 88.3 & 85 & 66.6 & 73.3 & 6. & 90 & 0 \\
\hline Ampicillin & 13.3 & 0 & 20 & 0 & 0 & 0 & 0 & 85 \\
\hline Tetracycline & 0 & 0 & 43.3 & 0 & 0 & 18.3 & 60 & 0 \\
\hline Cephaloridine & 35 & 0 & 23.3 & 0 & 0 & 0 & 30 & 0 \\
\hline Bacitracin & 16.6 & 0 & 0 & 0 & 0 & 0 & 0 & 0 \\
\hline Carbenicillin & 36.6 & 0 & 0 & 76.6 & 0 & 0 & 0 & 0 \\
\hline Nalidixic acid & 28.3 & 0 & 46.6 & 83.3 & 63.3 & 0 & 0 & 0 \\
\hline
\end{tabular}

Among antibiotics $85-95 \%$ curing was observed in three aerobic E. coli isolates (S-2, S-9, S-10) and one anaerobic Providencia isolate (SA-4) for kanamycin while one aerobic E. coli (S-2) and one anaerobic Providencia (SA-4) showed 85-90\% loss of resistance towards streptomycin. The anaerobic isolate, Providencia (SA-4) also showed $85 \%$ curing for ampicillin while none other isolate was found to be cured for ampicillin. One of the aerobic E. coli isolate (S-11), not showing curing for most of the antibiotics tested was found to lose $83.3 \%$ of resistance after curing towards Nalidixic acid. Spontaneous loss of resistance was also observed in the same isolates for kanamycin and chromium.

\section{Discussion}

Bacterial resistance may be due to the presence of R-plasmid containing genes for both antibiotics \& heavy metals (Timoney et al, 1978; Calomiris et al, 1984). Metal tolerance may also be related to the production of capsular polysaccharides usually by Enterobacter group of organisms, which can combine with metals to protect themselves from the toxicity of metals (Bitton \& Freihofer, 1978). More often the resistance phenomenon is plasmid borne and transferable in nature resulting its spread among the sensitive aquatic bacteria including coliforms.

The detection of elevated rate of tolerance to heavy metals in the present study as is depicted in Fig 3 may also reflect an adaptive response to the presence of toxic elements 
in marine environment in addition to the gut-intestine of Skua itself. However, the tolerance to heavy metal toxicity can also be influenced by several environmental factors like constituents of ecosystem, ion interactions, $\mathrm{pH}$, the form and availability of metals to the microbes. Thus, bacterial tolerance to metal toxicity is a significant environmental phenomenon (Sterritt and Lester, 1980; Jones et al, 1986).

The results show 59\% bacterial isolates from skua faeces are resistant to more than one antibiotic (MAR) (Fig. 7), which may be related to the process of bacterial survival and adaptation, and/or to the inconstancy of selective pressure in the environment. A number of reports confirm the presence of antibiotic resistant bacteria present in the soil samples from Antarctica (Shivaji et al, 1988, 1989a, 1989b).

Plasmid borne nature of resistance is evident by their spontaneous loss and curing by curative agents. Among antibiotics, resistance to Kanamycin was stable in most of the isolates while single isolate reported $80-90 \%$ curing for streptomycin and Nalidixic acid respectively indicating their plasmid-linked inheritance. Chromium and cobalt heavy metals also indicate their plasmid-mediated inheritance as $70-100 \%$ curing was observed by most of the isolates for these two heavy metals.

Ray et al, 1991 have isolated antibiotic resistant plasmid from Antarctic soil bacteria. Such bacteria may have evolved due to ecological interaction among the antibiotic producing strains and other strains lacking resistance. The bacteria carrying R-plasmids have a greater chance of survival and propagation in natural ecosystems than that of the strains lacking plasmids (Grabow et al. 1975,). Such plasmid carrying bacteria from Antarctica need detailed investigation. As the enzymatic machinery of these microbes is always under stress due to extreme cold condition, they seem to acquire enzymes, which are cold active, heat-labile and freeze-thaw resistant (Shivaji et al, 1994). But, as yet, the exact mechanism by which there microorganisms sense low temperature and adapt to these conditions is unknown. Whether these enzymes linked genes are plasmidmediated or not will reflect for a new avenue for survival among psychrotrophs through psychrophilic enzymatic machinery.

The incidence of plasmids in bacteria is reported to be greater in polluted compared to clearer sites (Hada \& Sizemore, 1981). Hence, in Antarctica, especially in those regions free of human intervention, the frequency of plasmids should be low. Our studies detected plasmids in eight and of twenty-two bacterial isolates indicating the lower artificial selection pressure due to human interference in Antarctica.

Earlier research on heavy metal and organochlorine pollution in Antarctic wildlife identified the brown skua (Catharacta lonnbergi) and the south polar skua (Catharacta maccormicki) as having some of the highest pollutant levels of all birds sampled (Norheim et al, 1982; Risebrongh and Carmignani, 1972; Gardner et al, 1985). Hence, it is possible that these species may be the marine equivalents of certain raptors, which show light pollutant loads through exposure to polluted environments when migrating and on wintering grounds (Cade and Fyfe, 1970; Peakall et al., 1976).

The present study sheds light on the pollution level in the Antarctic marine as well as terrestrial ecosystem and through the isolation of plasmid-bone characters provides better biotechnological prospects for survival in the fluctuating extreme external environment. 
Acknowledgements. PWR wish to thank Director, National Centre for Antarctic and Ocean Research (Department of Ocean Development), Vasco-de-Gamma, Goa, for providing an opportunity to be a summer member of $18^{\text {th }}$ Indian Scientific Expedition to Antarctica. Financial support by Council of Scientific and Industrial Research (CSIR) is gratefully acknowledged. The authors are thankful to CSIR, Govt of India for financial assistance.

\section{REFERENCES:}

[1] Anderson JD (1968): The ecology of transferable drug resistance in the enterobacteria. Ann. Rev. Microbiol. 22: 131-180.

[2] APHA (1992): Standard Methods for the Examination of Water and Wastewater. $-18^{\text {th }}$ American Public Health Association. American Water Works Association, Water Environmental Federation, Washington, D. C., 981 pp.

[3] Bauer AW, Kirby WMM, Sherries JC and Turck M (1966): Antibiotic susceptibility testing by a standardized single disk method. - American J. Clinical Pathology, 45: 493496.

[4] Bhattacherjee JW, Pathak SP and Gaur A (1988): Antibiotic resistance and metal tolerance of coliform bacteria isolated from Gomati river water at Lucknow city. - J. Gen. Appl. Microbiol. 34: 391-399.

[5] Bitton G and Freihofer V (1978): Influence of extra-cellular polysaccharides on the toxicity of copper and cadmium towards Klebsiella aerogenes. - Microbiol. Ecol. 4: 119.

[6] Bourne WRP (1976): Seabirds and pollution. - In: Marine pollution, Volume 6, pp. 403502. Ed. By R. Johnston. Academic Press, London.

[7] Bull KR, Murton RK, Osborn D, Ward P and Cheng L (1977): High levels of cadmium in Atlantic seabirds and sea-skaters. - Nature, 269: 507-509.

[8] Cade TJ and Fyfe RW (1970): The North American Peregrine Falcon survey. - Canadian Field-Naturalist 84: 231-245.

[9] Calomiris JJ, Armstrong JL, and Seidler RJ (1984): Association of metal tolerance with multiple antibiotic resistance of bacteria isolated from drinking water. - Appl. Environ. Microbiol. 47: 1238-1242.

[10] Cervantes C, Chavez J, Cardova NA, de la Mora P and Velasco JA (1986): Resistance to metal by Pseudomonas aeruginosa clinical isolates. - Microbios 48: 159-163.

[11] Cowan ST and Steel KJ (1974): Manual for identification of medical bacteria. - The Cambridge University Press, London, p. 80.

[12] Devillers P (1977): The skuas of the North American Pacific Coast. - Auk 94: 417-429.

[13] Fullager PJ (1976:) McCormick's Skua, Catharacta macckormicki, in the North Atlantic. - Australasian Seabird Group Newsletter, 7: 18-19.

[14] Furness RW (1987): The Skuas. - T. \& A. D. Poyser Ltd, Staffordshire, UK.

[15] Furness RW and Hutton M (1979): Pollutant levels in the Great Skua Catharacta skua. Environmental Pollution 13: 261-268.

[16] Furness RW and Hutton M (1980): Pollutants and impaired breeding success of Great Skuas Catharacta skua in Britain. - Ibis 122: 88-94.

[17] Furness RW and Camphuysen CJ (1997): Seabirds as monitors of the marine environment. - ICES Journal of Marine Science 54: 726-737.

[18] Furness RW and Monaghan P (1987): Seabird ecology. - Blackie, Glasgow. 164 pp.

[19] Furness RW (1993): Birds as monitor of pollutants. - In: Birds as monitors of environmental change. Chapman and Hall, London. 356 pp.

[20] Gardner BD, Siegfried WR and Connell AD (1985): Chlorinated hydrocarbons in seabird eggs from the Southern Atlantic and Indian Oceans. - In: Antarctic Nutrient Cycles and Food Webs, eds W. R. Siegfried, P. R. Condy and R. M. Laws. Springer-Verlag, Berlin. 
[21] Grabow WOK, OW Prozesky and JS Burger (1975): Behavior in a river and dam of coliform bacteria with transferable or non-transferable drug resistance. - Water Res. 9:777-782.

[22] Hada HS and Sizemore RK (1981): Incidence of plasmids in marine Vibrio spp. isolated from and oil field in the northwestern Gulf of Mexico. - Appl. Environ. Microbiol. 41: 199-202.

[23] Jones JG, Gardener S, Simon BM, Pickup RW (1986): Antibiotic resistant bacteria in Windemere and two remote upland tarns in the English Lake District. - Journal of Applied Bacteriology, 60: 443-453.

[24] Norheim G, Somme L and Holt G (1982): Mercury and persistent chlorinated hydrocarbons in Antarctic birds from Bouvetoya and Dronning Maud Land. Environmental Pollution 28: 233-240.

[25] Peakall DA (1976): The Peregrine Falcon and pesticides. - Canadian Field-Naturalist 90: 301-307.

[26] Ray MK, Kumar GS and Shivaji S (1991): Plasmids from soil bacteria Schirmacher Oasis, Antarctica. - Microbioscience 67: 151-157.

[27] Risebrough RW and Carmiguani M (1972): Chlorinated hydrocarbons in Antarctic birds. - Proceedings of the Symposium of Conservation Problems in Antarctica, ed. B. C. Parker. Allen Press, Lawrence, Kansas.

[28] Shivaji S, Rao NS, Saisree L, Sheth V, Reddy GS, Bhargava P M (1989b): Isolation and identification of Pseudomonas spp. from Schirmacher Oasis, Antarctica. - Appl Environ Microbiol. 55(3): 767-770.

[29] Shivaji S, Chattopadhyay MK and Ray MK (1994): Bacteria and yeast of Schirmacher Oasis, Antarctica: Taxonomy, Biochemistry and Molecular Biology. - Proc. NIPR Symp. Polar Biol. 7: 173-184.

[30] Shivaji S, Rao NS, Saisree L, Reddy GSN, Kumar GS and Bhargava PM (1989a): Isolates of arthrobacter from the soils of Schirmacher Oasis, Antarctica. - Polar Biol. 10: 225-229.

[31] Shivaji S, Rao NS, Saisree L, Sheth V, Reddy GS, Bhargava PM (1988): Isolation and identification of Micrococcus roseus and Planococcus sp. from Schirmacher oasis. Antarctica. J. Biosci. 13: 409-414.

[32] Sterritt RM and Lester JN (1980): Interactions of heavy metals with bacteria. - Sci. Total Environ. 14: 5-17.

[33] Timoney JF, Port J, Giles J and Spanier J (1978): Heavy Metal and Antibiotic Resistance in the Bacterial Flora of Sediments of New York Bight. - Appl. Environ. Microbiol. 36: 465-472.

[34] Veit RR (1978): Some observations of South Polar Skuas (Catharacta maccormicki) on Georges Bank. - American Birds 32: 300-302. 